\title{
International Cooperation on the Repression of Piracy and Armed Robbery at Sea under the UNCLOS
}

\section{Yurika Ishii*}

As maritime criminal activities are increasingly committed across the borders, States have come to establish mechanisms of international cooperation to be implemented in territorial seas. This article examines such mechanisms with regards to the crime of piracy and armed robbery at sea from the perspective of public international law. This article tackles the significance of the mechanisms imposed on the zonal approach, particularly paying attention to the nature of these crimes. It concludes that under the frameworks, States are allowed to pursue various objectives such as securing the safety of navigation, maintaining security, or protecting the local economy. They do not, however, fundamentally alter the nature of the zonal approach. Nonetheless, by setting up a forum of dialogue between the coastal States and the user States, it promotes maritime governance of territorial seas.

\section{Keywords}

Piracy, Armed Robbery at Sea, Law of the Sea, Maritime Security, International Cooperation.

* Assistant Professor at the National Defense Academy of Japan. LL.B./Ph.D. (Tokyo), LL.M.(Tokyo / Cornell). ORCID: http://orcid.org/0000-0001-5846-8341. The author may be contacted at: eureka@nda.ac.jp / Address: National Defense Academy of Japan (Dept. of International Relations), 1-10-20 Hashirimizu Yokosuka, Kanagawa Pref. 239-8686 Japan.

DOI: http://dx.doi.org/10.14330/jeail.2014.7.2.02 


\section{Introduction}

This article examines the impact of international cooperation mechanisms with regards to the crime of piracy and armed robbery at sea under international law. 'Piracy' is defined as "illegal acts of violence, detention or any act of depredation committed on the high seas" under Article 15 of the High Seas Convention ${ }^{1}$ and Article 105 of the United Nations Convention on the Law of the Sea ("UNCLOS"). "Armed robbery at sea" is a violent act against ships or persons committed in the territorial sea. ${ }^{3}$ While the definitional elements of armed robbery at sea are far from settled under international law, the common divisor is that the crime is committed in an area which is exclusively under a State's jurisdiction. ${ }^{4}$ E.g., the Code of Practice for the Investigation of the Crimes of Piracy and Armed Robbery against Ships adopted by International Maritime Organization ("IMO") defines "armed robbery against ships" as "any unlawful act of violence or detention or any act of depredation, or threat thereof, other than act of piracy, directed against a ship or against persons or property on board such a ship, within a State's jurisdiction over such offences." 5 This article would use this term in consistent with the IMO's definition.

The occurrence of piracy and armed robbery at sea was relatively infrequent during the Cold War. ${ }^{6}$ It was not until the late 1990s that the increase of these crimes raised serious concerns. ${ }^{7}$ The number of incidents in the post-Cold War era has increased primarily due to political and economic instability and poverty in developing countries. ${ }^{8}$ In addition, as the US and the former Soviet Union partially withdrew their naval forces in Southern Hemisphere, in particular in the Indian Ocean, States' control over the area was loosened, which pushed the escalation of the maritime violence. ${ }^{9}$

1 Convention on the High Seas, Apr. 29, 1958, 450 U.N.T.S. 82.

2 United Nations Convention on the Law of the Sea, Dec.10, 1982, 1833 U.N.T.S. 397.

3 R. Geiss \& A. Petrig, Piracy and Armed Robbery at Sea: The Legal Framework for Counter-Piracy Operations in Somalia And the Gulf of Aden 73 (2011).

$4 \quad I d$.

5 International Maritime Organization, Code of Practice for the Investigation of the Crimes of Piracy and Armed Robbery against Ships, IMO Doc. A22/Res.1922 (Jan. 22, 2009), available at http://www.imo.org/blast/blastDataHelper. asp?data_id=24575\&filename=A922(22).pdf(last visited on Oct. 25, 2014).

6 For details, see D. Rosenberg \& C. Chung, Maritime Security in the South China Sea: Coordinating Coastal and User State Priorities, 39 OCEAn DeV. \& InT'L L. 51 (2008).

7 Id. See also. R. Churchill \& A. V. Lowe, Law of the Seas 210, n.13 (1999).

8 Geiss \& Petrig, supra note 3, at 286.

9 S. Davidson, International law and the suppression of maritime violence, in INTERNATIONAL CONFLICT AND SECURITY Law: Essays in Memory of Hilaire McCoubrey 265 (R. Burchill, et al. eds., 2005). See also J. Kraska, Contemporary 